Jurnal Penelitian Hutan Tanaman Vol 18 No. 2, Desember 2021, 79-91

ISSN: 1829-6327, E-ISSN: 2442

Terakreditasi No: 21/E/KPT/2018

\title{
Organisasi dan Keragaan Pasar Durian: Studi Kasus di Desa Sungai Langka, Kecamatan Gedong Tataan, Provinsi Lampung (Market Organization and Performance of Durian: Case Study at Sungai Langka Village, Gedong Tataan District, Lampung Province)
}

\section{Rommy Qurniati*, Ari Yudha Prasetya, Susni Herwanti, dan/and Machya Kartika Tsani}

\author{
Jurusan Kehutanan, Fakultas Pertanian, Universitas Lampung. Jl. Sumantri Brojonegoro 1, Bandar \\ Lampung, 35145, Lampung, Indonesia \\ *E-mail: rommy.qurniati@fp.unila.ac.id
}

Tanggal diterima: 21 Maret 2021; Tanggal disetujui: 24 Mei 2021; Tanggal direvisi: 22 Juni 2021

\begin{abstract}
Durian production is a source of annual income for community living adjacent to the Wan Abdul Rahman Great Forest Park. Since, durian has a high economic value for the community, it is necessary to have an efficient marketing. The objective of this research was to analyse the market performance and organization of the durian market in its marketing system. The study was conducted in Januari until June 2019 on farmers and marketing institutions of durian at Sungai Langka Village, which is located on the boundary of the Wan Abdul Rachman Great Forest Park. Qualitative analysis was carried out to study the market organization and quantitative analysis was used to analyze market performance. The marketing of durian consists of four channels with a market structure that leads to oligopsony market at the farmer level and oligopoly at the marketing institutions (middlemen and retailers). The values of marketing margin, profit margin, ratio profit margin, and market share are not evenly distributed among all marketing institutions involved, therefore the durian marketing system is not efficient. Farmers need to collaborate with various parties to improve their capacity to produce high-quality durians and market them more efficiently.
\end{abstract}

Keywords: Market conduct, market structure, marketing channels, marketing efficiency, profit margin

\begin{abstract}
Abstrak
Hasil tanaman durian menjadi sumber penghasilan tahunan bagi masyarakat yang tinggal berbatasan dengan Taman Hutan Raya Wan Abdul Rahman (Tahura WAR), agar durian dapat memberikan nilai ekonomi yang tinggi bagi masyarakat, maka dibutuhkan sistem pemasaran yang efisien. Penelitian ini bertujuan untuk menganalisis organisasi dan keragaan pasar pada sistem pemasaran durian. Penelitian dilakukan pada Januari sampai Juni 2019 pada petani dan lembaga pemasaran durian di Desa Sungai Langka, Kecamatan Gedung Tataan, Kabupaten Pesawaran yang berbatasan dengan Tahura WAR. Analisis kualitatif dilakukan untuk mengkaji organisasi pasar dan analisis kuantitatif digunakan untuk menganalisa keragaan pasar. Pemasaran durian terdiri dari empat saluran dengan struktur pasar oligopsoni di tingkat petani dan oligopoli di lembaga pemasaran (tengkulak dan pengecer). Nilai margin pemasaran, margin keuntungan, rasio profit margin, dan pangsa
\end{abstract}


pasar belum merata diantara semua lembaga pemasaran yang terlibat, sehingga sistem pemasaran durian belum efisien. Petani perlu melakukan kerja sama dengan berbagai pihak untuk meningkatkan kapasitasnya dalam memproduksi durian yang berkuliatas dan memasarkannya secara lebih efisien.

\section{Kata kunci: Efisiensi pemasaran, margin keuntungan, perilaku pasar, saluran} pemasaran, struktur pasar

\section{Pendahuluan}

Taman Hutan Raya Tahura Wan Abdul Rachman (Tahura WAR) di Provinsi Lampung merupakan kawasan pelestarian alam dengan luas $22.245,50$ ha yang terbagi menjadi blok perlindungan, koleksi, rehabilitasi, pemanfaatan, tradisional, dan khusus (UPTD Tahura WAR, 2017). Blok tradisional dikelola masyarakat dengan membudidayakan tanaman kehutanan, pertanian, dan Multi Purpose Tree Species (MPTS). Salah satu jenis MPTS yang ditanam di kawasan Tahura WAR adalah durian (Durio zibethinus Murr) (Wulandari, Qurniati, \& Herwanti, 2018; Prasetya, Qurniati, \& Herwanti, 2020). Buah durian merupakan buah kering dengan tipe buah capsule dan didalamnya berisi daging buah (Dang \& Nguyen, 2015) yang umumnya berwarna putih hingga kekuningan, dengan rasa manis dan enak (Harmiatun, Sunarto, \& Gultom, 2018). Cita rasa durian yang khas banyak diminati masyarakat, sehingga mendorong petani untuk membudidayakannya.

Potensi buah durian di Tahura WAR mencapai 387.139 gandeng (774.278 buah) per tahun atau jika dirupiahkan setara dengan $\mathrm{Rp}$ 9.059.052.600,00 (UPTD Tahura WAR, 2017). Potensi ini menjadikannya sebagai sumber penghasilan tahunan bagi petani durian. Salah satu pusat produksi durian di Tahura WAR adalah di Desa Sungai Langka dimana pada tahun 2018 ditetapkan sebagai Desa Agrowisata di Provinsi Lampung. Dalam rangka mempromosikan dan mendukung pengembangan buah durian lokal, pada Januari 2019 Pemerintah Daerah Provinsi Lampung mengadakan kontes buah durian di desa ini. Durian yang menjadi pemenang akan dikembangkan menjadi produk unggulan nasional.

Durian memiliki prospek yang menjanjikan baik dari segi permintaan maupun harga pasarnya. Nilai ekonomi buah durian dapat membantu pemenuhan kebutuhan ekonomi masyarakat (Hikmah, Retnoningsih, \& Habibah, 2016). Dalam memasarkan buah durian, petani sebagai produsen menggunakan lembaga pemasaran untuk mendistribusikan buah durian sampai ke konsumen akhir (Kurnia, Herdiansah, \& Hardiyanto, 2016). Namun, penelitian pemasaran durian di Desa Wonoagung dan Kelurahan Sumber Agung menunjukkan bahwa keuntungan yang diterima petani masih rendah dibandingkan dengan keuntungan yang diperoleh lembaga pemasarannya (Baladina, Anindita, \& Ariani, 2011; Wulandari et al., 2018). Umumnya upaya promosi dan pengembangan durian di Desa Sungai Langka dapat berhasil, maka perlu dilakukan penelitian untuk menganalisis organisasi dan keragaan pasar pada sistem pemasaran durian di Desa Sungai Langka.

\section{Metodologi}

\subsection{Lokasi dan Waktu Penelitian}

Penelitian ini dilakukan di Desa Sungai Langka, Kecamatan Gedong Tataan, Kabupaten Pesawaran yang merupakan salah satu desa penyangga di Tahura WAR. Penelitian dilaksanakan pada bulan Januari sampai Juni 2019.

\subsection{Metode}

Objek penelitian ini adalah 44 petani durian dan 10 lembaga pemasaran durian (5 pedagang pengumpul dan 5 pengecer) yang 
terdapat di Desa Sungai Langka. Penentuan jumlah responden petani menggunakan Formula Slovin dari populasi 198 petani dan penentuan lembaga pemasaran menggunakan snowball sampling. Pada penelitian ini saluran pemasaran durian dibatasi sampai Ibukota Provinsi Lampung.

Data penelitian terdiri dari data primer dan sekunder. Data primer meliputi data organisasi pasar dan keragaan pasar. Data sekunder terdiri dari data tentang kondisi umum Tahura WAR dan data produksi durian di Provinsi Lampung.

Konsep organisasi pasar dianalisis secara kualitatif menggunakan variabel struktur pasar, perilaku pasar, dan saluran pemasaran. Struktur pasar dianalisis untuk mengidentifikasi jumlah lembaga pemasaran, distribusi produk pada berbagai konsentrasi pasar, jenis produk yang ada di pasar, dan kemudahan atau hambatan lembaga lain yang akan masuk ke pasar durian (Wulandari et al., 2018). Analisis perilaku pasar digunakan untuk mempelajari bagaimana praktek jual beli durian, sistem penentuan harga, pembayaran, dan kerja sama yang terjadi antar lembaga pemasaran. Saluran pemasaran dianalisis untuk mengamati panjang pendeknya rantai pasar durian dari produsen sampai ke konsumen akhir.

Tabel (Table) 1. Tabel indikator pengukuran (Measurement indicator table)

\begin{tabular}{|c|c|c|}
\hline $\begin{array}{l}\text { Konsep } \\
(\text { Concept })\end{array}$ & $\begin{array}{l}\text { Variabel } \\
\text { (Variable) }\end{array}$ & Indikator pengukuran (Measurement indicator) \\
\hline \multirow{3}{*}{$\begin{array}{l}\text { Analisis } \\
\text { organisasi } \\
\text { pasar (Market } \\
\text { organization } \\
\text { analysis) }\end{array}$} & $\begin{array}{l}\text { Struktur pasar } \\
\text { (Market } \\
\text { structure) }\end{array}$ & $\begin{array}{l}\text { (1) Jumlah lembaga suatu pasar (Number of institutions in a } \\
\text { market); (2) Distribusi lembaga pemasaran dalam berbagai } \\
\text { ukuran dan konsentrasi (Distribution of market institutions in } \\
\text { various sizes and concentrations); (3) Jenis-jenis produk yang } \\
\text { dipasarkan (Types of products being marketed); (4) Kebebasan } \\
\text { lembaga lain untuk keluar masuk pasar (Freedom of other } \\
\text { institutions to enter and exit the market) }\end{array}$ \\
\hline & $\begin{array}{l}\text { Perilaku pasar } \\
\text { (Market } \\
\text { conduct) }\end{array}$ & $\begin{array}{l}\text { (1) Praktek penjualan dan pembelian (Selling and buying } \\
\text { practices); (2) Sistem penentuan dan pembayaran harga (Price } \\
\text { determination and payment system); (3) Kerja sama antar } \\
\text { lembaga pemasaran (Cooperation between marketing } \\
\text { institutions) }\end{array}$ \\
\hline & $\begin{array}{l}\text { Saluran } \\
\text { pemasaran } \\
\text { (Marketing } \\
\text { channel) }\end{array}$ & $\begin{array}{l}\text { Alur lintas produk dari produsen sampai ke konsumen akhir } \\
\text { (The flow of product from producerto end consumer) }\end{array}$ \\
\hline \multirow{4}{*}{$\begin{array}{l}\text { Keragaan } \\
\text { pasar (Market } \\
\text { performance) }\end{array}$} & $\begin{array}{l}\text { Margin } \\
\text { pemasaran } \\
(\text { Marketing } \\
\text { margin) }(\mathrm{Rp}) \\
\end{array}$ & $\begin{array}{l}\text { Selisih antara harga beli dan harga jual durian pada suatu } \\
\text { lembaga pemasaran (The difference between the purchase } \\
\text { price and the selling price of durian at a marketing agency) }\end{array}$ \\
\hline & $\begin{array}{l}\text { Margin } \\
\text { keuntungan } \\
\text { (Profit margin) } \\
(\mathrm{Rp})\end{array}$ & $\begin{array}{l}\text { Selisih margin keuntungan dan biaya pemasaran (The } \\
\text { difference in profit margin and marketing cost) }\end{array}$ \\
\hline & $\begin{array}{l}\text { Ratio profit } \\
\text { margin }(\mathrm{Rp})\end{array}$ & $\begin{array}{l}\text { Perbandingan margin keuntungan dan biaya pemasaran } \\
\text { (Comparison of profit margin and marketing cost). }\end{array}$ \\
\hline & $\begin{array}{l}\text { Market share } \\
(\%)\end{array}$ & $\begin{array}{l}\text { Persentase total dari penjualan suatu lembaga pemasaran } \\
\text { dengan penjualan pada konsumen akhir (The total percentage } \\
\text { of sales at a marketing institution with the final consumer) }\end{array}$ \\
\hline
\end{tabular}


Analisis kuantiatif pada konsep keragaan pasar dilakukan dengan menghitung margin pemasaran, margin keuntungan, ratio profit margin, dan market share. Indikator-indikator pengukuran yang digunakan pada analisis sistem pemasaran durian disajikan pada Tabel 1.

\section{Hasil dan Pembahasan}

\subsection{Hasil}

\subsubsection{Organisasi pasar}

Cara organisasi memfasilitasi pemasaran durian merujuk pada struktur dan perilaku serta keragaan pasarnya (Tabel 2).

\subsubsection{Struktur pasar}

Karakteristik pertama menunjukkan lembaga pemasaran yang terlibat dalam pemasaran durian terdiri dari pengumpul dan pengecer. Jumlah pengumpul yang ada di lokasi penelitian sebanyak delapan pengumpul namun yang dianalisis hanya lima pengumpul karena dianggap sudah mewakili. Jumlah ini lebih banyak dari pengecer yang hanya lima pedagang saja.

Karakteristik kedua menunjukkan jumlah pengumpul di desa tersebut lebih banyak dari pengecer. Hal ini disebabkan potensi produksi durian yang tinggi dan kemudahan akses menuju desa. Pedagang pengecer umumnya memiliki modal yang lebih kecil dibandingkan pengumpul, sehingga tidak mampu menampung durian dalam jumlah besar seperti pengumpul. Pengumpul memiliki jangkauan pasar yang luas, tidak hanya di Provinsi Lampung namun sampai ke Jakarta dan daerah lainnya, sedangkan pengecer memasarkan durian di pasar kecamatan atau ibukota provinsi yang tidak jauh dari desa. Hal ini dilakukan agar biaya pemasaran berupa biaya transportasi yang dikeluarkan dapat diminimalisir.

Karakteristik ketiga dilihat dari jenis produk yang dipasarkan. Produk durian yang dipasarkan terdiri dari durian jatuhan, durian unduhan dan tempoyak. Durian jatuhan adalah buah durian yang dipanen dengan cara memanen buah durian yang jatuh ke tanah secara alami bukan karena dipetik/dipanen. Buah durian yang jatuh umumnya adalah buah yang sudah matang, sehingga memiliki rasa lebih manis dibandingkan dengan durian unduhan namun kelemahannya lebih cepat busuk, sehingga membutuhkan waktu pemasaran yang lebih cepat. Berbeda dengan durian unduhan, durian ini dipanen secara serentak berdasarkan ukuran buah durian, sehingga tingkat kematangan buah durian bervariasi dan umumnya pemanenan dilakukan sebelum durian masak di pohon. Cara ini bertujuan agar durian tidak cepat busuk, sehingga waktu pemasarannya bisa lebih lama dan pemanenan dapat dilakukan sekaligus dalam jumlah banyak. Durian jatuhan dan unduhan yang sudah layu dan tidak layak untuk dijual diolah menjadi tempoyak. Tempoyak adalah fermentasi dari daging buah durian yang sudah masak sebagai bahan aneka masakan khas dari daerah Sumatera. Pengolahan tempoyak dilakukan untuk meminimalisir kerugian penjualan durian, namun tempoyak masih dikemas dengan cara sederhana dengan menggunakan plastik bening dan diikat dengan karet gelang. Selain tempoyak, belum ada inovasi lain yang dikembangkan oleh petani maupun lembaga pemasaran durian di Desa Sungai Langka untuk meningkatkan nilai tambah durian. Kalau petani bersedia melakukan berbagai inovasi teknik pengolahan durian (membuat dodol durian, sirop durian, menjual durian beku, dll), maka nilai tambah yang akan diperoleh dari penjualan durian akan signifikan.

Karakteristik keempat dilihat dari kemudahan lembaga pemasaran (pengumpul dan pengecer) keluar dan masuk pasar. Kemudahan keluar masuk pasar diartikan sebagai tingkat kesulitan (hambatan) bagi suatu individu/lembaga pemasaran untuk ikut memasarkan durian. Kemudahan pedagang untuk masuk ke pasar dapat dilihat dari besarnya modal yang dibutuhkan untuk memasarkan durian. Jika modal yang dibutuhkan sangat besar 
maka dapat menjadi hambatan lembaga pemasaran lain untuk masuk ke pasar. Berdasarkan wawancara dengan responden, modal pengumpul di lokasi penelitian berkisar antara $\mathrm{Rp} 10.000 .000,00$ -
Rp 25.000.000,00 sedangkan modal pengecer berkisar antara Rp 2.000.000,00 $\mathrm{Rp}$ 5.000.000,00. Hal ini berarti siapapun yang memiliki modal dapat masuk ke pasar durian di Desa Sungai Langka.

Tabel (Table) 2. Struktur, perilaku, dan saluran pemasaran durian di Desa Sungai Langka. (Structure, conduct, and channels of durian marketing in Sungai Langka Village)

\begin{tabular}{|c|c|}
\hline Organisasi pasar (Market organization) & Keterangan (Remarks) \\
\hline \multicolumn{2}{|l|}{ Struktur pasar (Market structure) } \\
\hline $\begin{array}{l}\text { Jumlah lembaga suatu pasar (The number of } \\
\text { institutions in a market) }\end{array}$ & 10 Lembaga (10 Institutions) \\
\hline $\begin{array}{l}\text { Distribusi lembaga pemasaran dalam ukuran } \\
\text { dan konsentrasi (Distribution of marketing } \\
\text { institutions in size and concentration) }\end{array}$ & $\begin{array}{l}5 \text { Pengumpul dan } 5 \text { pengecer ( } 5 \\
\text { Midlements and } 5 \text { retailers) }\end{array}$ \\
\hline $\begin{array}{l}\text { Jenis produk yang dipasarkan (Types of } \\
\text { product) }\end{array}$ & $\begin{array}{l}\text { Buah dan tempoyak (Fruit and } \\
\text { tempoyak) }\end{array}$ \\
\hline $\begin{array}{l}\text { Kebebasan lembaga keluar masuk pasar } \\
\text { (Independency of institutions to enter and } \\
\text { exit the market) }\end{array}$ & Mudah (Easy) \\
\hline \multicolumn{2}{|l|}{ Perilaku pasar (Market behavior) } \\
\hline $\begin{array}{l}\text { Praktek penjualan dan pembelian (Selling } \\
\text { and buying practices) }\end{array}$ & $\begin{array}{l}\text { Borongan dan eceran (Wholesale and } \\
\text { retail) }\end{array}$ \\
\hline $\begin{array}{l}\text { Sistem penentuan harga dan metode } \\
\text { pembayaran (Price determination and } \\
\text { payment methhod) }\end{array}$ & $\begin{array}{l}\text { Berdasarkan harga pasar dan tunai } \\
\text { (Based on market prices and cash } \\
\text { payments) }\end{array}$ \\
\hline $\begin{array}{l}\text { Kerja sama antar lembaga pemasaran } \\
\text { (Cooperation among market institutions) }\end{array}$ & $\begin{array}{l}\text { Ada kerja sama tetapi terbatas (There is } \\
\text { cooperation but limited) }\end{array}$ \\
\hline $\begin{array}{l}\text { Saluran pemasaran (Marketing channels) } \\
\text { Alur perjalanan produk mulai dari produsen } \\
\text { hingga sampai konsumen akhir (The flow of } \\
\text { product from producer to final consumer) }\end{array}$ & $\begin{array}{l}\text { 4 Saluran pemasaran meliputi: } \\
\text { (a) Saluran } 1 \text { (Petani-konsumen akhir) } \\
\text { (Channel } 1 \text { (Farmer-final } \\
\text { consumer)) } \\
\text { (b) Saluran } 2 \text { (Petani-pengecer- } \\
\text { konsumen akhir) (Channel } 2 \\
\text { (Farmer-retailer-final consumer)) } \\
\text { (c) Saluran } 3 \text { (Petani-pengumpul- } \\
\text { pengecer-konsumen akhir) } \\
\text { (Channels } 3 \text { (Farmer-midlement- } \\
\text { retailer-final consumer)) } \\
\text { (d) Saluran } 4 \text { (Petani-pengumpul- } \\
\text { konsumen luar daerah) (Channels } 4 \\
\text { (Farmer-midlement- consumers } \\
\text { outside the region ) }\end{array}$ \\
\hline
\end{tabular}




\subsubsection{Perilaku pasar}

Praktek penjualan dan pembelian durian dilakukan dengan sistem borongan dan eceran. Petani menjual durian ke pengumpul atau pengecer umumnya dengan cara borongan dalam jumlah besar baik untuk durian unduhan maupun durian jatuhan. Cara penjualan ditentukan oleh kuantitas durian yang akan dipasarkan. Durian dalam jumlah kecil dijual secara eceran dengan harga per satuan.

Penentuan harga durian dilakukan dengan cara tawar-menawar antara penjual dan pembeli numun pada akhirnya pengaruh penjual lebih kuat dalam penentuan harga. Harga borongan ditentukan dengan memprediksi jumlah durian tanpa memperhitungkan ukuran dan kualitasnya. Jika harga sudah disepakati, durian akan dibayar secara tunai. Pada saat produksi durian melimpah (panen raya), harga durian turun, sebaliknya pada saat jumlah produksi durian sedikit antara lain akibat cuaca buruk maka harga durian lebih tinggi. Penentuan harga eceran dilakukan per satuan dengan mempertimbangkan ukuran, kualitas, dan informasi harga pasar durian. Namun seringkali petani tidak memiliki informasi harga sebelum melakukan transaksi, sehingga melemahkan posisi tawar petani. Sebenarnya petani dapat mengakses informasi harga dan pasar melalui internet yang sudah dapat diakses sampai ke desa, tetapi masih sedikit petani yang mau dan mampu mengakses informasi tersebut untuk mendukung aktivitas pemasarannya.

Pemasaran durian masih dilakukan secara individu dan belum ada kerja sama pemasaran khususnya di tingkat petani. Kerja sama di tingkat lembaga pemasaran berupa kegiatan menampung durian yang tidak layak jual untuk diolah menjadi tempoyak. Pengolahan tempoyak baru dilakukan oleh satu pengumpul karena beberapa lembaga pemasaran enggan menjual durian yang sudah tidak layak jual dan membiarkannya membusuk dan dibuang daripada dijual dengan harga yang rendah ( $\operatorname{Rp} 3.000,00,-/$ buah), terlebih jika 84 lokasi pengolah jauh. Kendati demikian, kerja sama ini tetap menguntungkan karena dapat mengurangi risiko buah durian terbuang sia-sia.

\subsubsection{Saluran pemasaran}

Saluran pemasaran terbagi menjadi saluran pemasaran langsung oleh petani ke konsumen akhir atau disebut saluran non tingkat/zero level channel (Nurlia, Siahaan \& Lukman, 2013) dan saluran pemasaran tidak langsung melalui lembaga pemasaran (pengumpul dan pengecer), ke konsumen akhir (Gambar 2). Pedagang pengumpul merupakan lembaga pemasaran yang paling banyak menampung durian petani. Saluran pemasaran yang paling banyak digunakan petani adalah saluran 2 yaitu 39\% (Gambar 2). Petani memilih saluran pemasaran berdasarkan harga yang ditawarkan pedagang, jika harga telah disepakati maka penjualan dapat dilakukan.

\subsubsection{Keragaan pasar}

Keragaan pasar merupakan analisis yang dilakukan dengan menghitung margin pemasaran beserta penyebarannya untuk melihat efisiensi pemasaran durian. Harga jual petani tertinggi terdapat pada saluran pemasaran 1 dan 2 (Tabel 3) yang merupakan saluran terpendek. Namun hal ini bukan berarti bahwa panjang pendeknya saluran pemasaran selalu menunjukkan tinggi rendahnya harga yang diterima petani. Harga yang tinggi pada saluran 1 dan 2 dikarenakan durian yang dijual adalah durian jatuhan yang kualitasnya lebih terjamin, sehingga harganya tinggi. Berbeda dengan saluran 3 dan 4 yang menjual durian unduhan dengan cara borongan, kuantitas penjualan yang besar dan kualitas durian yang bervariasi menyebabkan harga yang diterima petani lebih rendah. Walaupun petani menyadari bahwa penjualan dengan cara borongan merugikan, namun posisi tawar petani sangat lemah. Produksi durian dalam jumlah besar hanya mampu ditampung oleh pedagang pengumpul di saluran 3 dan 4 
yang memiliki modal lebih besar dari pengecer. Selain itu, penjualan durian jatuhan memakan waktu lebih lama (dalam satu siklus produksi) karena buah jatuh tidak dalam waktu yang sama, sehingga pemanenan durian dilakukan setiap pagi dan sore dan pemasarannya dilakukan per hari dalam jumlah bervariasi tergantung ketersediaannya. Petani yang membutuhkan uang tunai dalam jumlah besar dan cepat akan memilih panen secara unduhan dan memasarkannya dengan cara borongan.

Pada saluran 1 tidak ada komponen biaya pemasaran. Biaya ini dihitung sejak meninggalkan titik produksi (petani), sehingga semua biaya yang dikeluarkan petani merupakan biaya produksi. Biaya pemasaran terbesar dikeluarkan pengecer pada saluran 3 yang membeli durian dari pengumpul dengan cara datang ke desa, sehingga pengecer harus mengeluarkan biaya angkut ke lokasi penjualan. Pada proses pengangkutannya, kualitas durian harus dijaga agar tidak rusak karena dapat menurunkan harga dan margin keuntungannya.

Margin keuntungan pada pengumpul saluran 4 lebih besar dari pengumpul saluran 3 memiliki nilai Ratio Profit Margin (RPM) lebih rendah. Nilai RPM ini menunjukkan keuntungan yang diperoleh per 1 rupiah biaya total yang dikeluarkan. Pengumpul saluran 4 mengeluarkan biaya pemasaran lebih besar dari pengumpul saluran 3. Jarak lokasi tujuan pemasaran yang berbeda menjadikan biaya pemasarannya berbeda hal ini menunjukkan bahwa pedagang pengumpul pada saluran 3 lebih efisien, namun sebaran nilai RPM pada berbagai lembaga pemasaran yang terlibat di keempat saluran tidak merata, sehingga sistem pemasaran durian belum efisien.

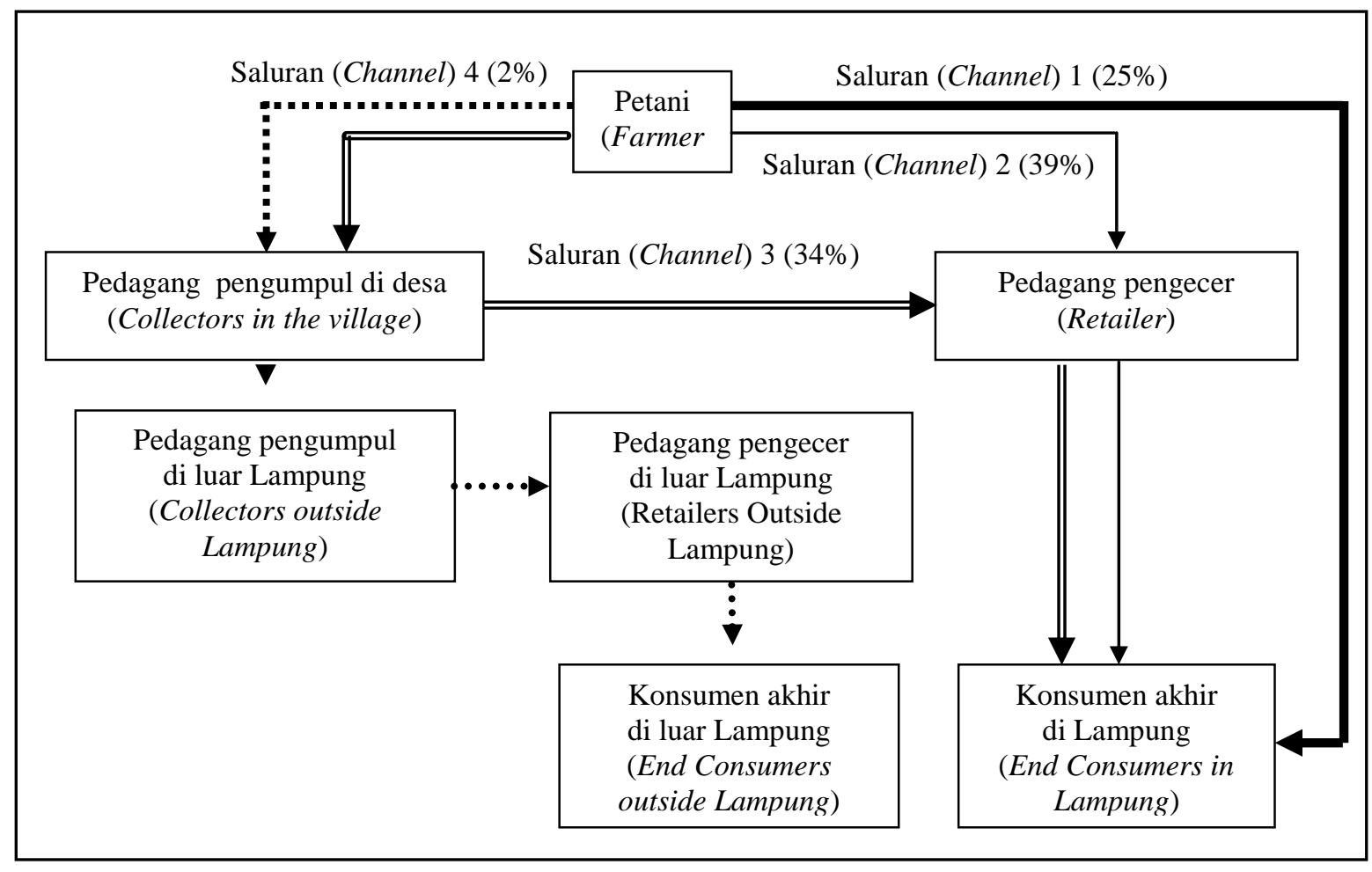

Gambar (Figure) 2. Saluran pemasaran durian di Desa Sungai Langka (Durian marketing channel in Sungai Langka Village) 
Tabel (Table) 3. Analisis margin pemasaran di Desa Sungai Langka (Analysis of marketing margin in Sungai Langka Village)

\begin{tabular}{|c|c|c|c|c|c|c|c|c|}
\hline \multirow[t]{2}{*}{ Uraian } & \multicolumn{2}{|c|}{$\begin{array}{c}\text { Saluran } 1 \text { (Channel } \\
\text { 1) }\end{array}$} & \multicolumn{2}{|c|}{ Saluran 2 (Channel 2) } & \multicolumn{2}{|c|}{ Saluran 3 (Channel 3) } & \multicolumn{2}{|c|}{$\begin{array}{c}\text { Saluran } 4 \\
\text { (Channel 4) }\end{array}$} \\
\hline & $\begin{array}{c}\text { Harga } \\
\text { (Price) } \\
\text { (Rp/Buah) } \\
\text { (Rp/Unit) }\end{array}$ & $\begin{array}{c}\text { Share } \\
(\%)\end{array}$ & $\begin{array}{c}\text { Harga } \\
\text { (Price) } \\
\text { (Rp/Buah) } \\
\text { (Rp/Unit) }\end{array}$ & $\begin{array}{c}\text { Share } \\
(\%)\end{array}$ & $\begin{array}{c}\text { Harga } \\
\text { (Price) } \\
\text { (Rp/Buah) } \\
\text { (Rp/Unit) }\end{array}$ & $\begin{array}{c}\text { Share } \\
(\%)\end{array}$ & $\begin{array}{c}\text { Harga } \\
\text { (Price) } \\
\text { (Rp/Buah) } \\
\text { (Rp/Unit) }\end{array}$ & $\begin{array}{l}\text { Share } \\
(\%)\end{array}$ \\
\hline 1. Harga jual petani (Farmer's Selling price) & 14.100 & 100 & 15.500 & 77,5 & 11.700 & 52 & 11.700 & $\underline{46,8}$ \\
\hline $\begin{array}{l}\text { 2. Harga jual pengumpul (Middleman's Selling } \\
\text { price at) }\end{array}$ & & & & & 19.000 & 84,44 & 25.000 & $\underline{100}$ \\
\hline 3. Biaya pemasaran (Marketing costs): & & & & & $\underline{25}$ & 0,11 & 220 & 0,88 \\
\hline - Tenaga kerja (Labor) & & & & & 0 & 0 & $\overline{100}$ & 0,4 \\
\hline - Transportasi (Transportation) & & & & & 25 & 0,11 & 120 & 0,48 \\
\hline 4. Margin pemasaran (Marketing margin) & & & & & 7.300 & 32,44 & 13.300 & 53,2 \\
\hline 5. Margin keuntungan (Profit margin) & & & & & $\underline{7.275}$ & 32,33 & 13.080 & 52,32 \\
\hline 6. Ratio profit margin (Profit margin ratio) & & & & & 291 & & $\overline{59,45}$ & \\
\hline 7. Harga jual pengecer (Selling price of retailer) & & & 20.000 & $\underline{100}$ & $22 . \overline{500}$ & $\underline{100}$ & & \\
\hline 9. Biaya pemasaran (Marketing costs): & & & $\underline{405}$ & $\overline{2,02}$ & $\underline{1.857}$ & $\overline{8,25}$ & & \\
\hline - Tenaga kerja (Labor) & & & 0 & 0 & $\overline{1.000}$ & 4,44 & & \\
\hline - Transportasi (Transportation) & & & 405 & 2,02 & 857 & 3,80 & & \\
\hline 10. Margin pemasaran (Marketing margin) & & & 4.500 & 22,5 & 3.500 & 15,55 & & \\
\hline 11. Resiko pemasaran (Marketing risk) $20 \%$ & & & 900 & 4,5 & 700 & 3,11 & & \\
\hline 12. Margin keuntungan (Profit margin) & & & $\underline{3.195}$ & 15,97 & $\underline{943}$ & 4,19 & & \\
\hline $\begin{array}{l}\text { 13. Rasio margin keuntungan (Ratio Profit } \\
\text { Margin) }\end{array}$ & & & $\underline{7,88}$ & & $\overline{0,50}$ & & & \\
\hline $\begin{array}{l}\text { 14. Harga beli konsumen akhir (Purchase price of } \\
\text { final consumer) }\end{array}$ & 14.100 & 100 & 20.000 & 100 & 22.500 & 100 & 25.000 & 100 \\
\hline
\end{tabular}

Sumber (Source): Data primer (2019) (Primary data (2019)) 


\subsection{Pembahasan}

Pemasaran durian merupakan kegiatan memindahkan durian dari produsen hingga sampai ke konsumen akhir yang dimulai setelah durian meninggalkan titik awal produksi, yaitu petani. Produksi durian oleh petani meliputi kegiatan pembibitan, penanaman, pemangkasan, penyiraman, pemupukan, pengendalian hama dan penyakit hingga pemanenan. Kegiatan setelah itu adalah pemasaran durian yang mencakup segala kegiatan yang berhubungan dengan perpindahan hak milik dan fisik durian, termasuk kegiatankegiatan tertentu yang menghasilkan perubahan bentuk untuk lebih memudahkan penyaluran dan memberikan kepuasan yang lebih tinggi kepada konsumen (Qurniati, 2019).

Agar produk sampai ke konsumen akhir, lembaga pemasaran menjalankan berbagai fungsi pemasaran, yaitu fungsi pertukaran, fisik, dan fasilitas (Kusuma, Kaskoyo, \& Qurniati, 2020). Fungsi pertukaran adalah kegiatan memperlancar perpindahan hak milik melalui fungsi pembelian dan penjualan (Qurniati, 2019). Pembelian dilakukan oleh pedagang pengumpul dari petani baik di kebun ataupun rumah petani sedangkan pengecer melakukan pembelian dari pengumpul di rumah pengumpul atau di pasar. Kondisi ini serupa dengan penelitian Annisa, Asmarantaka, \& Nurmalina (2018) di Kabupaten Brebes Provinsi Jawa Tengah yang menunjukkan bahwa lembaga pemasaran terlebih dahulu mengambil produk dari petani, kemudian produk tersebut akan dijual kembali di pasaran. Pembelian durian secara langsung dari petani adalah upaya untuk mendapatkan persediaan durian dengan harga murah untuk kemudian dipasarkan hingga sampai ke konsumen akhir.

Fungsi fisik merupakan semua tindakan yang langsung berhubungan dengan buah durian, sehingga menimbulkan kegunaan tempat, bentuk, dan waktu. Fungsi ini berhubungan dengan fungsi penyimpanan, pengolahan, dan pengangkutan (Qurniati, 2019). Fungsi penyimpanan tidak dilakukan oleh lembaga pemasaran durian mengingat sifat durian yang mudah rusak. Fungsi pengolahan juga terbatas pada pembuatan tempoyak saja. Tempoyak memiliki kegunaan bentuk karena durian diubah bentuknya menjadi tempoyak yang memiliki jangka waktu lebih lama untuk dikonsumsi, sehingga ada kegunaan waktu karena penggemar durian tetap dapat mengkonsumsinya kendati musim durian telah berlalu. Pengangkutan durian oleh lembaga pemasaran menggunakan motor atau mobil mulai dari titik awal produksi, yaitu kebun durian hingga dapat dinikmati oleh konsumen menimbulkan kegunaan tempat terutama bagi konsumen yang tinggal jauh dari pusat produksi durian. Selain itu Chaerani (2016) menyatakan, pengangkutan yang dilakukan lembaga pemasaran telah memberi kemudahan bagi petani dalam penyampaian durian ke konsumen.

Fungsi fasilitas adalah semua tindakan yang bertujuan memperlancar kegiatan pertukaran yang terjadi antara produsen dan konsumen. Fungsi fasilitas terdiri dari fungsi standardisasi dan grading, penanggungan resiko, pembiayaan, dan informasi pasar (Qurniati, 2019). Standardisasi dan grading dilakukan oleh petani dan pengecer yang melakukan pemasaran durian dengan cara eceran. Hal yang sama ditemukan pada penelitian Sabrina, Winandi, \& Rachmina (2013) tentang pemasaran durian di Pasar Induk Kramat Jati, bahwa fungsi standardisasi hanya dilakukan oleh pedagang pengecer dan supermarket. Sebelum dijual, durian dipilih dan dikelompokkan berdasarkan standar yang ada, sehingga diperoleh harga yang berbeda untuk masing-masing grade. Penentuan harga didasarkan pada kualitasnya dan ini dapat memberikan nilai tambah bagi petani dan lembaga pemasaran yang melakukannya. Menurut pengumpul dan pengecer yang terdapat di Desa Sungai Langka, penanggungan risiko adalah 
kerugian akibat penurunan kualitas durian karena lamanya waktu penjualan yang menyebabkan penurunan harga jual durian ataupun risiko tidak laku. Resiko paling tinggi pada pemasaran durian berada di tingkat pengecer. Pengumpul memiliki resiko paling rendah karena menjual durian dengan cara borongan, sehingga mampu menyalurkan seluruh durian dalam waktu lebih cepat.

Petani selaku penjual durian Desa Sungai Langka menghadapi struktur pasar oligopsoni, yaitu struktur pasar yang terdiri dari jumlah penjual yang banyak dan pembelinya sedikit, hal ini dapat terjadi karena jumlah petani (sebagai penjual) lebih banyak dibandingkan dengan lembaga pemasaran dan konsumen akhir yang membeli durian. Akibatnya, posisi petani durian di Desa Sungai Langka menjadi lemah dalam menentukan harga durian yang dipasarkan. Hal ini sejalan dengan hasil penelitian Wulandari et al., (2018) yang mendapatkan jumlah petani sebagai penjual lebih banyak dari pembeli, sehingga posisi petani hanya sebagai penerima harga dan bukan yang menentukan harga.

Pengumpul dan pengecer menghadapi struktur pasar oligopoli, yaitu struktur pasar yang terdiri dari beberapa penjual dan banyak pembeli dengan produk yang homogen. Pedagang pengumpul langsung membeli atau mengumpulkan durian dari beberapa petani untuk dijual kembali pada pedagang pengumpul di luar daerah dan atau pengecer, sehingga jumlah pembelinya lebih banyak dari penjual, hal ini dilakukan pengumpul untuk memperluas jaringan pemasaran durian. Begitu pula dengan pengecer yang jumlahnya lebih sedikit dibandingkan dengan konsumen akhir sebagai pembeli yang lebih banyak jumlahnya. Pengecer menjual secara eceran (per satuan) kepada konsumen akhir. Cara ini lebih menguntungkan karena margin keuntungan per satuan durian lebih tinggi dibandingkan dengan cara borongan namun kuantitas yang terjual umumnya lebih sedikit. Cara eceran biasanya dilakukan pedagang pengecer dan petani.

Struktur pasar oligopoli memberikan kekuatan pada pedagang untuk menetapkan harga jual yang tinggi, sehingga diperoleh margin keuntungan yang tinggi. Margin keuntungan tertinggi terdapat pada pengumpul saluran 4 . Kondisi ini berbeda dengan hasil penelitian Wulandari et al., (2018) dimana keuntungan terbesar terdapat pada pengecer. Harga jual yang tinggi dapat menutup biaya transportasi dan biaya tenaga kerja untuk memasarkan durian. Informasi akan tingginya harga durian di luar daerah dan kemampuan modal yang dimiliki pengumpul, mendorong terjadinya pemasaran durian ke luar daerah seperti Palembang dan beberapa kota di Pulau Jawa, yaitu Jakarta, Bogor, dan Bandung.

Dari segi peluang pedagang untuk masuk ke pasar durian di Desa Sungai Langka, tidak ada hambatan khusus. Hambatan yang ditemukan terutama terkait dengan sistem pembayaran yang harus dilakukan secara tunai baik pada tingkat petani, pengumpul, maupun pengecer, sehingga diperlukan modal uang tunai yang cukup untuk dapat masuk ke pasar durian. Selain modal, tidak ada hambatan lain pada pemasaran durian di Desa Sungai Langka seperti yang ditemukan pada penelitian Sinaga \& Dewi (2016), dimana terdapat ikatan yang kuat antara petani dan pedagang, baik dalam bentuk pinjaman modal maupun kesepakatan yang dibuat secara kolektif, sehingga dapat menjadi hambatan bagi lembaga pemasaran yang akan masuk ke pasar. Kemudahan lembaga pemasaran untuk masuk dan keluar pasar merupakan salah satu indikasi pemasaran yang efisien. Menurut Permadi (2017) jika akses pasar sulit, maka akan menjadi kendala utama dalam efisiensi suatu pemasaran.

Pengetahuan mengenai kualitas durian merupakan hal yang penting bagi petani dan lembaga pemasaran sebagai dasar dalam melakukan standardisasi, grading, dan penentuan harga durian. Untuk memperoleh 
durian dengan kualitas yang baik diperlukan teknik budi daya dan teknik penanganan buah paska panen yang tepat (Krismawati, 2012). Penanganan paska panen meliputi kegiatan pengumpulan, penyortiran, penggolongan, penyimpanan, pengemasan, dan pengangkutan. Selain itu, untuk memperpanjang umur simpan durian dan memberikan nilai tambah bagi petani dapat dilakukan teknologi penyimpanan dingin dan teknologi pengolahan. Tanaman yang baik diperoleh melalui bibit unggul, penanaman, pemeliharaan sampai dengan pengendalian kerusakan tanaman. Hasil penelitian Indriyanto, Asmarahman, \& Tsani (2020) mendapatkan bahwa tanaman durian di Tahura WAR mengalami berbagai kerusakan pada organ tubuh tanamannya meskipun dengan nilai kerusakan yang ringan, yaitu $8,3 \%$. Namun, jika tidak ditanggulangi dengan tepat, kerusakan dapat berdampak pada kualitas durian, sehinga perlu dilakukan berbagai upaya untuk menghasilkan durian berkualitas baik. Selain melihat kualitas duriannya, penentuan harga juga berdasarkan informasi harga dan kecenderungan harga di pasaran.

Penelitian Nahraeni, Rahayu, Yoesdiarti, \& Kulsum (2018) menunjukkan bahwa informasi harga yang diperoleh petani hanya berasal dari pembeli bukan informasi yang berasal dari pasar, sehingga memungkinkan terjadinya kepalsuan informasi. Kemudahan informasi berkaitan dengan letak daerah, daerah yang letaknya strategis dan memiliki akses ke kota cepat, tidak sulit memperoleh informasi harga yang berlaku. Jarak Desa Sungai Langka yang tidak terlalu jauh dari ibukota Provinsi Lampung (14 km atau 35 menit dengan mobil) dan sarana jalan yang bagus sampai ke desa memudahkan akses ke petani durian. Namun cukup disayangkan kemudahan informasi harga baru dinikmati oleh pedagang. Kontes buah durian yang diselenggarakan oleh Pemerintah Daerah Lampung di Desa Sungai Langka merupakan salah satu upaya untuk menjembatani penyampaian informasi harga ke petani dan membuka peluang kerja sama dengan peserta kontes atau pengunjung selaku konsumen durian. Hal ini sesuai dengan Sudrajat, Mulyo, Hartono, \& Subejo (2015) yang menjelaskan bahwa, salah satu faktor yang mendukung keberlangsungan usaha adalah hubungan kerja sama yang terjalin antar pihak yang terkait dengan pemasaran durian. Kerja sama antara petani dengan berbagai pihak perlu dilakukan untuk meningkatkan kapasitas petani agar dapat meningkatkan pedapatannya yang barasal dari tanaman durian.

Penurunan produksi buah durian terjadi di Kabupaten Pesawaran dari 93.461 kwintal pada tahun 2018 menjadi 16.710 kwintal durian tahun 2019 (Badan Pusat Statistik Provinsi Lampung, 2020). Penurunan yang cukup besar ini tentu memengaruhi pendapatan dari durian. Salah satu upaya yang dapat dilakukan adalah dengan memperluas penanaman durian pada kawasan hutan di dalam wilayah Tahura WAR melalui skema kemitraan konservasi. Kemitraan konservasi merupakan salah satu upaya penyeimbang antara kepentingan konservasi dengan kepentingan keberlanjutan kesejahteraan masyarakat. Kemitraan konservasi dilakukan di dalam dan di sekitar kawasan konservasi dengan memberikan jaminan akses kepada masyarakat untuk memanfaatkan kawasan konservasi (Prayitno, 2020). Selain memperoleh jaminan akses, petani juga akan mendapatkan pendampingan dari berbagai pihak, sehingga pemanfaatan kawasan dapat memberikan nilai tambah tidak hanya bagi masyarakat berupa pemanfaatan hasil hutan bukan kayu, namun juga bagi peningkatan fungsi kawasan hutan. Kemitraan konservasi merupakan salah satu upaya untuk memberdayakan dan mengembangkan masyarakat yang ada di sekitar kawasan hutan dan sekaligus dapat mengurangi terjadinya tekanan masyarakat terhadap hutan yang ada disekitarnya (Hartoyo, Purtri, \& Pambudi, 2020). 


\section{Kesimpulan dan Saran}

\subsection{Kesimpulan}

Organisasi dan keragaan pasar durian membentuk struktur pasar oligopsoni pada tingkat petani dan oligopoli pada tingkat lembaga pemasaran (pengumpul dan pengecer). Pada struktur ini petani dan konsumen akhir memiliki kemampuan yang rendah dalam memengaruhi harga. Saluran pemasaran durian meliputi empat saluran dengan saluran terpendek, yaitu dari petani langsung ke konsumen akhir dan saluran terpanjang adalah saluran yang memasarkan durian ke luar daerah (petani-pedagang pengumpul desa-pedagang pengumpul luar daerah-pengecer-konsumen akhir). Nilai margin pemasaran, margin keuntungan, dan RPM belum merata pada semua lembaga pemasaran, sehingga menyebabkan pemasaran durian di Sungai Langka belum efisien.

\subsection{Saran}

Perlu dilakukan inovasi pada budi daya tanaman durian agar diperoleh kualitas buah durian dengan cara melakukan pemeliharaan tanaman dan peremajaan tanaman-tanaman tua menggunakan bibit unggul yang diperoleh melalui pencarian sumber benih unggul yang ada atau melalui pengadaan benih terpercaya. Selain itu untuk meningkatkan efisiensi pemasaran durian, perlu dilakukan kerja sama dengan para pihak terutama Tahura WAR agar petani memiliki legalitas dalam pemanfaatan hasil hutan dan dapat membantu petani mengatasi masalahmasalah keterbatasan modal, teknologi, peningkatan kualitas durian, diversifikasi produk durian, jaringan pemasaran, dan informasi harga terkini untuk memperkuat posisi tawar petani dan mengembangkan strategi pemasaran yang lebih efisien.

\section{Ucapan Terima Kasih}

Terima kasih kepada pihak UPTD Taman Hutan Raya Wan Abdul Rachman dan Pemerintah Desa Sungai Langka yang telah membantu dalam proses perizinan dan kelengkapan data penelitian ini. Selain itu, terima kasih juga kami sampaikan pada Dr. Wahyu Hidayat, S.Hut., M.Si. atas masukannya dalam penelitian ini.

\section{Daftar Pustaka}

Annisa, I., Asmarantaka, R., \& Nurmalina, R. (2018). Efisiensi pemasaran bawang merah (kasus: Kabupaten Brebes Provinsi Jawa Tengah). Jurnal Ilmiah Manajemen, 8(2), 254-271.

Badan Pusat Statistik Provinsi Lampung. (2020). Provinsi Lampung Dalam Angka 2020. Bandar Lampung: Badan Pusat Statistik Provinsi Lampung.

Baladina, N., Anindita, R., \& Ariani, R. (2011). Analisis efisiensi pemasaran durian di Desa Wonoagung, Kecamatan Kasembon, Kabupaten Malang. Jurnal Habitat, 22(1), 1-11.

Chaerani, D.S. (2016). Margin dan efisiensi pemasaran kopra Di Desa Simalegi Kecamatan Siberut Barat Kabupaten Kepulauan Mentawai. Jurnal BibieT, 1(2), 81-94.

Dang, T.N., \& Nguyen, B.H., (2015). Study on durian processing technology and defleshing machine. Asia Pacific Journal of Sustainable Agriculture, Food and Energy, 3(1), 12-16.

Harmiatun, Y., Sunarto, \& Gultom, M. (2018). Pemanfaatan limbah biji durian (Durio zibethinus Murr) sebagai bahan baku pembuatan tempe alternatif melalui proses fermentasi oleh jamur Rhizopus oligosporus. Jurnal Pro-Life, 5(1), 526-533.

Hartoyo, D., Purtri, E.F., \& Pambudi, K.S., (2020). Kemitraan konversi dan masa depan hutan Papua. Dinamika Sosial Budaya, 22(2), 148-157.

Hikmah, R., Retnoningsih, A., \& Habibah, N. (2016). Keragaman durian 
berdasarkan fragmen Internal Transcribed Spacers (ITS) DNA ribosomal melalui analisis PCR-RFLP. Jurnal MIPA Unnes, 39(1), 11-18.

Indriyanto, Asmarahman, C., \& Tsani, M. K. (2020). Identifikasi kerusakan tegakan hutan di areal garapan petani KPPH Kuyung Bawah dalam Kawasan Tahura Wan Abdul Rachman. Journal of Tropical Upland Resources, 02(02), 150-161.

Krismawati, A. (2012). Keunggulan dan potensi pengembangan sumber daya genetik durian Kalimantan Tengah. Buletin Plasma Nutfah, 18(2), 70-76.

Kurnia, D., Herdiansah, D., \& Hardiyanto, T. (2016). Analisis saluran pemasaran gabah (Oriza sativa) di Gapoktan Sauyunan. Jurnal Agroinfo Galuh, 2(3), 167-172.

Kusuma, R.B., Kaskoyo, H., \& Qurniati, R. (2020). Efisiensi pemasaran kayu sengon (Falcataria moluccana) di areal Hutan Rakyat Pekon Lengkukai, Kabupaten Tanggamus, Provinsi Lampung. Jurnal Penelitian Hutan Tanaman, 17(2), 101-116.

Nahraeni, W., Rahayu, A., Yoesdiarti, A., \& Kulsum, I. (2018). Struktur pasar sayuran kemangi di Pasar Tradisional. Jurnal Agribisnis, 40(2), 21-29.

Nurlia, A., Siahaan, H., \& Lukman, A.H., (2013). Pola pemanfaatan dan pemasaran nibung di sekitar kawasan Taman Nasional Sembilang Provinsi Sumatera Selatan. Jurnal Penelitian Hutan Tanaman, 10(4), 241-251.

Permadi, R. (2017). Analisis efisiensi pemasaran pisang kepok di Kabupaten Seruyan. Jurnal Agricultural Scienties, 1(1), 120-128.

Prasetya, A.Y. (2019). Peran modal sosial dalam mendukung kegiatan pemasaran durian (Durio zibethinus) di Tahura Wan Abdul Rachman. Skripsi. Universitas Lampung.
Prasetya, A.Y., Qurniati, R., \& Herwanti, S. (2020). Saluran dan margin pemasaran durian hasil agroforestri di Desa Sidodadi. Jurnal Belantara, 3(1), 3240.

Prayitno, D.E. (2020). Kemitraan konservasi sebagai upaya penyelesaian konflik tenurial dalam pengelolaan kawasan konservasi di Indonesia. Jurnal Hukum Lingkungan Indonesia, 6(2), 184-209.

Qurniati, R. (2019). Pemasaran Hasil Hutan. Sleman: Graha Ilmu.

Sabrina, Winandi, R., \& Rachmina, D. (2013). Pemasaran durian di Pasar Induk Kramat Jati. Forum Agribisnis, 3(2), 187-200.

Sinaga, S., \& Dewi, N. (2016). Pemasaran buah nenas (Kajian struktur, perilaku, dan penampilan pasar) di Desa Kualu Nenas Kecamatan Tambang Kabupaten Kampar. Jurnal Ilmiah Pertanian, 13(1), 38-50.

Sudrajat, J., Mulyo, J., Hartono, S., \& Subejo. (2015). Peranan social capital dalam memelihara keberlanjutan agribisnis jagung. Jurnal Masyarakat, Kebudayaan, Dan Politik, 28(3), 139152.

UPTD Tahura WAR. (2017). Blok Pengelola Tahura Wan Abdul Rachman. Laporan Kegiatan. Bandar Lampung.

Wulandari, D., Qurniati, R., \& Herwanti, S. (2018). Efisiensi Pemasaran Durian (Durio zibethinus) di Desa Wisata Durian Kelurahan Sumber Agung. Jurnal Sylva Lestari, 6(2), 68. 